\title{
Analisis Cost-Effectiveness Seftazidim Generik pada Pasien Kanker Payudara di Rumah Sakit Kanker "Dharmais" Jakarta, 2012
}

\author{
NADIA FARHANAH SYAFHAN ${ }^{1}$, AGUSDINI BANUNSAPTANINGSIH ${ }^{2}$, MUTIARA JEANY RAHAYU PERTIWI ${ }^{1}$ \\ ${ }^{1}$ Fakultas FarmasiUniversitas Indonesia \\ ${ }^{2}$ Direktorat Jendral Farmalkes Kementrian Kesehatan Republik Indonesia.
}

Diterima: 4 April 2016; Direview: 11 April 2016; Disetujui: 2 Mei 2016

\section{KORESPONDENSI:}

Nadia Farhanah Syafhan Fakultas Farmasi

Universitas Indonesia

Email: n.farhanah@ui.ac.id

\begin{abstract}
Administration of ceftazidime shortened duration of neutropenia and hospitalization days in breast cancer patients who had infection after myelosupressive chemotherapy. Cost-effectiveness analysis (CEA) as one of pharmacoeconomic methods was important to determine treatment attaining effect for lower cost. The aim of this study was to compare the total direct medical cost and effectiveness, which was measured from length-of-stay (LOS), of generic ceftazidime $A$ and B usage, and to decide which ceftazidime that was more cost-effective in early-stage and late-stage breast cancer patients at National Cancer Center Dharmais Hospital Jakarta year 2012. The study design was non-experimental with comparative study retrospectively on secondary data from medical records and administrative data in 2012. Samples were taken by using total sampling method. The number of samples were 9 patients, which included 7 patients with generic ceftazidime $A$ and 2 patients with generic ceftazidime $B$. The total direct medical cost of generic ceftazidime $A$ in early-stage and late-stage breast cancer patients, respectively $R p$ 15.930.407,45 and $R p$ 15.962.519,25, were higher than generic B, respectively Rp 6.716.225,21 and Rp 7.147.956,92. Median LOS of generic A ceftazidime in early-stage and late-stage breast cancer patients, respectively 7 days and 10 days, were longer than generic $B$, respectively 3 days and 4 days. According to CEA result, generic ceftazidime $B$ was more cost-effective than generic $A$.
\end{abstract}

Keyword: breast cancer; ceftazidime; cost-effectiveness; generic; infection

\begin{abstract}
ABSTRAK
Pemberian seftazidim dapat mempersingkat durasi neutropenia dan lama hari rawat inap pada pasien kanker payudara yang mengalami infeksi setelah kemoterapi mielosupresif. Analisis cost-effectiveness merupakan salah satu metode farmakoekonomi yang penting untuk menentukan obat efektif dengan biaya yang lebih rendah. Penelitian dilakukan untuk membandingkan total biaya medis langsung dan efektivitas yang dilihat dari lama hari rawat penggunaan seftazidim generik A dan B, serta menentukan seftazidim yang lebih cost-effective pada pasien kanker payudara stadium awal dan lanjut di Rumah Sakit Kanker "Dharmais" Jakarta, 2012. Desain penelitian yang digunakan adalah studi komparatif secara retrospektif terhadap data rekam medis dan administrasi tahun 2012. Pengambilan sampel dilakukan secara total sampling. Jumlah pasien yang dilibatkan dalam analisis 9 pasien, yaitu 7 pasien menggunakan seftazidim generik A dan 2 pasien menggunakan seftazidim generik B. Median total biaya medis langsung kelompok generik A pada pasien kanker stadium awal maupun lanjut berturut-turut sebesar Rp 15.930.407,45 dan Rp 15.962.519,25 lebih tinggi dibanding generik B, berturut-turut sebesar Rp 6.716.225,21 dan Rp 7.147.956,92. Median lama hari rawat kelompok generik A pada pasien kanker stadium awal maupun lanjut berturut-turut 7 hari dan 10 hari, lebih panjang dibanding generik B, berturut-turut 3 hari dan 4 hari. Berdasarkan hasil penelitian disimpulkan bahwa seftazidim generik B lebih cost-effective dibanding generik A.
\end{abstract}

Kata Kunci: cost-effectiveness, generik, infeksi, kanker payudara, seftazidim 


\section{PENDAHULUAN}

Seftazidim merupakan antibiotik golongan $\checkmark$ sefalosporin generasi ketiga yang menjadi pilihan terapi antibiotik empiris lini pertama untuk infeksi pada pasien kanker payudara karena aktivitasnya cukup luas dalam melawan bakteri gram-negatif dan gram-positif.' Egerer et al., (2002) mengungkapkan bahwa median durasi neutropenia pasca-kemoterapi pada kanker payudara adalah sebelas hari dan menurun menjadi delapan hari setelah dimulainya terapi seftazidim sehingga pemberian seftazidim dapat mengurangi kebutuhan hospitalisasi. ${ }^{2}$ Variasi harga sediaan seftazidim generik yang beredar dari berbagai pabrik farmasi dapat memberikan variasi besaran biaya pengobatan. Hal ini memicu perlunya dilakukan penelitian untuk mengetahui jenis seftazidim yang lebih menguntungkan dalam menangani infeksi pasca-kemoterapi pada pasien kanker payudara stadium awal dan lanjut di Rumah Sakit Kanker "Dharmais", Jakarta, selaku rumah sakit rujukan nasional penyakit kanker. Studi farmakoekonomi merangkum aspek ekonomi, yaitu pengidentifikasian, penghitungan, dan pembandingan biaya serta aspek konsekuensi farmasetika dan klinis produk obat. ${ }^{3}$ Rumah Sakit Kanker "Dharmais", Jakarta, menggunakan seftazidim generik A dan B dalam formulariumnya. Analisis efektivitas biaya membantu memberikan alternatif yang optimal yang tidak selalu berarti biayanya lebih murah, tetapi mengidentifikasi dan mempromosikan terapi pengobatan yang paling efisien. ${ }^{4}$ Belum tersedianya data mengenai analisis efektivitas biaya penggunaan antibiotik seftazidim di Rumah Sakit Kanker "Dharmais" Jakarta mendasari peneliti untuk mengetahui pemberian antibiotik seftazidim yang paling cost-effective pada pasien kanker payudara stadium awal dan lanjut.

Penelitian ini bertujuan untuk menganalisis antibiotik mana yang lebih cost-effective antara seftazidim generik A dan generik B pada pasien kanker payudara stadium awal dan lanjut di Rumah Sakit Kanker "Dharmais", Jakarta.

\section{MATERI DAN METODE}

Desain penelitian yang digunakan adalah noneksperimental dengan studi perbandingan (comparative study). Pengambilan data dilakukan secara retrospektif terhadap data sekunder berupa catatan rekam medis serta data administrasi tahun
2012. Hasil penelitian disajikan secara deskriptif dan analitik. Penelitian dilakukan di Rumah Sakit Kanker "Dharmais" Jakarta bagian rekam medis dan administrasi dari bulan Februari sampai Mei 2013.

Populasi adalah data semua pasien kanker payudara yang dirawat inap pada tahun 2012 di Rumah Sakit Kanker "Dharmais", Jakarta. Sampel penelitian adalah data semua pasien kanker payudara yang dirawat inap pada tahun 2012 yang memenuhi kriteria inklusi di Rumah Sakit Kanker "Dharmais", Jakarta. Pengambilan sampel dilakukan secara total sampling, yaitu jumlah semua sampel yang memenuhi kriteria inklusi.

Kriteria inklusi penelitian di antaranya data pasien berjenis kelamin wanita, pasien yang menjalani kemoterapi sebelum diberikan antibiotik, dan pasien yang mendapatkan inisial terapi tunggal antibiotik seftazidim generik. Kriteria eksklusi meliputi data pasien yang rekam medisnya tidak lengkap, hilang, dan tidak jelas serta pasien kanker payudara metastasis tulang.

Analisis univariat digunakan untuk menggambarkan data demografi pasien dan disajikan secara deskriptif berupa tabel, analisis bivariat dilakukan pada total biaya medis langsung dan efektivitas (lama hari rawat) antara penggunaan seftazidim generik A dan generik B dengan uji Mann-Whitney. Efektivitas biaya dianalisis dengan menentukan posisi alternatif pengobatan dalam diagram efektivitas biaya. Biaya yang dilihat adalah biaya pengobatan, bukan rerata efektivitas biaya. Tiap jenis antibiotik seftazidim yang digunakan diperbandingkan total biaya rawatnya dengan melakukan penghitungan rasio rerata efektivitas biaya $(\mathrm{REB}=$ Average Cost Effectiveness Ratio/ACER) yang dihitung berdasarkan total biaya medis langsung yang dikeluarkan pasien kanker payudara terhadap efektivitas penggunaan antibiotik, yaitu lama hari rawat, dengan rumus:

$$
\operatorname{REB}(A C E R)=\frac{\text { Total biaya medis langsung }}{\text { Lama hari rawat }}
$$

Analisis sensitivitas dilakukan untuk mengetahui sejauh mana perubahan nilai biaya atau efektivitas yang digunakan untuk menghitung REB dapat memengaruhi kesimpulan. ${ }^{5}$ Analisis sensitivitas untuk analisis efektivitas biaya antibiotik dilakukan dengan melakukan variasi penurunan dan kenaikan 25\% terhadap total biaya. ${ }^{6}$ 


\section{HASIL DAN PEMBAHASAN}

Terdapat 514 pasien kanker payudara yang mendapatkan kemoterapi di RSKD pada tahun 2012. Sebanyak 18 pasien menggunakan seftazidim pascakemoterapi dan yang memenuhi kriteria inklusi didapatkan sembilan pasien kanker payudara yang memenuhi kriteria inklusi dengan perincian tujuh pasien menggunakan seftazidim generik A dan dua pasien menggunakan seftazidim generik B. Data karakteristik subjek penelitian dapat dilihat pada Tabel 1. Jumlah pasien yang sedikit dalam penelitian ini kemungkinan berhubungan dengan rendahnya tingkat kejadian infeksi pasca-kemoterapi pada pasien kanker payudara yang harus diterapi dengan ceftazidim. Menurut Polednak (2004) dalam studi surveilans pada pasien kanker payudara di USA yang didiagnosis sebelum usia 65 tahun, kebutuhan rawat inap karena kondisi terkait infeksi (neutropenia, demam, dan/atau infeksi/bakteremia) adalah 8,6\% dari 463 pasien dengan kemoterapi dan 2,8\% dari 212 pasien tanpa kemoterapi (nilai signifikan $\mathrm{p}<$ 0,01). ${ }^{7}$ Pemberian G-CSF (Granulocyte-Colony Stimulating Factor) sebagai terapi profilaksis terhadap risiko neutropenia pasca -kemoterapi juga dapat mengurangi risiko febril neutropenia dari 17\% menjadi $1 \%$, serta mengurangi kebutuhan rawat inap dari $14 \%$ menjadi $1 \%{ }^{8}$

Median usia pasien kanker payudara yang mendapat seftazidim selama periode penelitian adalah 54 tahun dengan pasien terbanyak berasal dari kelompok usia 40-49 tahun, yaitu empat pasien $(44,5 \%)$. Banyaknya pasien yang berusia 40 tahun ke atas dikarenakan pada usia ini risiko terkena kanker payudara semakin besar. Kanker payudara mulai berkembang pesat saat umur 40-49 tahun sebelum wanita memasuki usia 50 tahun ke atas. Sedangkan risiko kanker payudara sendiri berkembang sampai usia 50 tahun dengan perbandingan peluang 1 di antara 50 wanita. ${ }^{9}$ Lebih dari 60\% pasien berasal dari luar Jakarta. Hal ini sesuai dengan tujuan RSKD sebagai rumah sakit rujukan pusat nasional sehingga pasien yang datang tidak hanya berasal dari dalam kota Jakarta, namun banyak juga yang berasal dari luar Jakarta.

Lebih dari 50\% pasien kanker payudara yang masuk dalam penelitian ini merupakan pasien kanker payudara stadium lanjut dengan tiga pasien di antaranya merupakan pasien kanker payudara metastasis, yaitu dua $(22,2 \%)$ pasien mengalami metastasis paru dan satu $(11,1 \%)$ pasien mengalami metastasis hati. Pasien dengan metastasis hati sebanyak satu orang dimasukkan dalam kriteria inklusi karena berdasarkan penelitian Pasko, M.T.; Beam, T.R.; Sponer, J.A.; dan Camara, D.S. (1985) mengenai studi keamanan dan farmakokinetika seftazidim pada pasien gangguan hati kronis diperoleh kesimpulan bahwa pemberian seftazidim tetap stabil dan normal sehingga modifikasi dosis seftazidim pada gangguan hati tidak diperlukan. ${ }^{10}$ Pasien kanker payudara dengan metastasis tulang dieksklusi karena hasil hitung darah lengkap mungkin menunjukkan menurunnya jumlah leukosit dan trombosit karena keterlibatan sumsum tulang yang mengganggu kebutuhan peryaratan parameter hematologi yang mendekati normal. ${ }^{11,12}$

Jumlah kemoterapi terbanyak yang menyebabkan infeksi dengan tanda penurunan jumlah leukosit dan demam pada pasien regimen AC (doxorubisin -siklofosfamid) yaitu empat pasien dari keseluruhan pasien, diikuti tiga pasien dengan regimen AT (doxorubisinpaclitaxel/docetaxel) dan dua pasien dengan FAC (fluorourasil-doxorubisinsiklofosfamid). Hal ini sedikit kurang sesuai dengan pernyataan Aapro et al., (2011) dan National Comprehensive Cancer Network (2013) yang mengategorikan regimen kemoterapi dengan risiko tinggi (>20\%) febril neutropenia, yaitu AT, AC yang dilanjutkan dengan Taxan dan TAC. Sementara, AC, FAC, dan Taxan termasuk dalam risiko sedang $(10 \%-20 \%) .{ }^{13,14}$ Regimen kemoterapi dengan risiko tinggi kemungkinan diatasi dengan pemberian inisial terapi seftazidim yang dikombinasi dengan antibiotik lain. Pemberian inisial kombinasi antibiotik menguntungkan untuk pengobatan infeksi campuran, pengobatan awal pada infeksi berat yang etiologinya belum jelas karena keterlambatan pengobatan dapat membahayakan jiwa pasien, untuk mendapatkan efek sinergi, dan memperlambat timbulnya resistansi. Kombinasi sefalosporin dengan aminoglikosida bermanfaat untuk infeksi Pseudomonas pada pasien neutropenia. ${ }^{15,16}$

Diagnosis febril neutropenia dan leukopenia ditegakkan oleh dokter dalam catatan rekam medis berdasarkan keadaan demam (suhu lebih dari $38^{\circ} \mathrm{C}$ dalam satu jam atau dua kali pengukuran) yang dialami pasien dan jumlah leukosit dari pemeriksaan hematologi. Pengobatan empiris infeksi pascakemoterapi dengan antibiotik seftazidim segera diberikan pada sembilan pasien yang masuk dalam kriteria inklusi. Sebanyak delapan $(88,9 \%)$ pasien mengalami febril neutropenia pasca-kemoterapi yang dijalaninya, sedangkan satu $(11,1 \%)$ pasien lain diberi terapi antibiotik empiris seftazidim dengan diagnosis leukopenia. 
Tabel 1: Karakteristik subjek penelitian berdasarkan total pasien dan jenis seftazidim yang digunakan di Rumah Sakit Kanker 'Dharmais" Jakarta tahun 2012

\begin{tabular}{llll} 
Karakteristik Pasien & $\begin{array}{c}\text { Total } \\
(\mathbf{N = 9})\end{array}$ & $\begin{array}{c}\text { Generik A } \\
(\mathbf{N}=7)\end{array}$ & $\begin{array}{c}\text { Generik B } \\
(\mathbf{N}=2)\end{array}$ \\
\hline Usia (\%) & & & \\
$40-49$ tahun & $4(44,5)$ & $3(42,86)$ & $1(50)$ \\
$50-59$ tahun & $2(22,2)$ & $2(28,57)$ & $0(0)$ \\
$>60$ tahun & $3(33,3)$ & $2(28,57)$ & $1(50)$ \\
Median & 54 & 54 & 55,5 \\
Rentang & $41-63$ & $41-63$ & $48-63$ \\
\hline
\end{tabular}

\section{Asal daerah (\%)}

\begin{tabular}{llll} 
Jakarta & $3(33,3)$ & $3(42,86)$ & $0(0)$ \\
Luar Jakarta & $6(66,7)$ & $4(57,14)$ & $2(100)$ \\
\hline
\end{tabular}

\begin{tabular}{llll}
\hline $\begin{array}{l}\text { Pekerjaan (\%) } \\
\text { Ibu Rumah Tangga }\end{array}$ & $7(77,8)$ & $6(85,71)$ & $1(50)$ \\
Swasta & $2(22,2)$ & $1(14,29)$ & $1(50)$ \\
\hline Pendidikan & & & \\
Tamat SD & $2(22,2)$ & $2(28,57)$ & $0(0)$ \\
Tamat SMA & $5(55,6)$ & $4(57,14)$ & $1(50)$ \\
Tamat Sarjana & $2(22,2)$ & $1(14,29)$ & $1(50)$ \\
\hline Jaminan pembiayaan (\%) & & & \\
ASKES & $5(55,5)$ & $4(57,14)$ & $1(50)$ \\
Jamkesmas & $2(22,2)$ & $2(28,57)$ & $0(0)$ \\
Jaminan Perusahaan & $2(22,2)$ & $1(14,29)$ & $1(50)$
\end{tabular}

\begin{tabular}{|c|c|c|c|}
\hline Jamınan Peru & $\angle(\angle L, \angle)$ & $1(14, \angle y)$ & $1(50)$ \\
\hline \multicolumn{4}{|c|}{ Jenis kamar rawat inap (\%) } \\
\hline Kelas I dan VIP & $4(44,4)$ & $3(42,86)$ & $1(50)$ \\
\hline Kelas II dan III & $5(55,6)$ & $4(57,14)$ & $1(50)$ \\
\hline \multicolumn{4}{|l|}{ Stadium (\%) } \\
\hline Awal (I-IIIA) & $4(44,4)$ & $3(42,86)$ & $1(50)$ \\
\hline Lanjut (IIIB-IV) & $5(55,6)$ & $4(57,14)$ & $1(50)$ \\
\hline \multicolumn{4}{|l|}{ Kondisi metastasis (\%) } \\
\hline Tidak metastasis & $6(66,7)$ & $5(71,42)$ & $1(50)$ \\
\hline Paru & $2(22,2)$ & $1(14,29)$ & $1(50)$ \\
\hline Hati & $1(11,1)$ & $1(14,29)$ & $0(0)$ \\
\hline \multicolumn{4}{|l|}{ Kemoterapi (\%) } \\
\hline FAC & $2(22,2)$ & $2(28,57)$ & $0(0)$ \\
\hline$A C$ & $4(44,5)$ & $2(28,57)$ & $2(100)$ \\
\hline AT & $3(33,3)$ & $3(42,86)$ & $0(0)$ \\
\hline \multicolumn{4}{|l|}{ Derajat Leukopenia (\%) } \\
\hline Leukopenia grade III & $1(11,1)$ & $1(14,29)$ & $0(0)$ \\
\hline Febril neutropenia & $8(88,9)$ & $6(85,71)$ & $2(100)$ \\
\hline \multicolumn{4}{|l|}{ Pemberian G-CSF } \\
\hline ya & $8(88,9)$ & $6(85,71)$ & $2(100)$ \\
\hline tidak & $1(11,1)$ & $1(14,29)$ & $0(0)$ \\
\hline
\end{tabular}

Keterangan:

ASKES $=$ Asuransi kesehatan, Jakesmas $=$ Jaminan Kesehatan Masyarakat,

$F A C=$ flourourasil/doxorubisin/siklofosfamid, $A C=$ doxorubisin/siklofosfamid, $\mathrm{AT}=$ doxorubisin/taxan, $\mathrm{G}-\mathrm{CSF}=$ granulocyte-colony stimulating factor
Sebagian besar pasien, yaitu $8(88,9 \%)$ orang mendapat terapi tambahan faktor pertumbuhan (G-CSF) untuk mengatasi leukopenia dan neutropenia. G-CSF diberikan pada pasien secara intravena atau subkutan dengan dosis $300 \mu \mathrm{g}$ per vial satu sampai dua kali sehari. G-CSF diberikan hingga jumlah leukosit pasien minimal $2000 \mathrm{sel} / \mu \mathrm{l} .{ }^{17}$

Data perbedaan lama hari rawat, suhu demam, dan pemberian G-CSF tiap kelompok seftazidim pada pasien kanker payudara stadium awal dan lanjut dapat dilihat pada Tabel 2 dan Tabel 3. Median lama hari rawat pada pasien kanker payudara stadium awal sedikit lebih singkat dibanding lama hari rawat pasien kanker payudara stadium lanjut (7 hari dibanding 8,5 hari). Menurut Hai Pun et al., (2009), perawatan di rumah sakit dibutuhkan pada pasien dengan demam dan neutropenia untuk menghindari komplikasi yang tidak diinginkan. Meski hal ini akan mengurangi risiko kematian, pasien mungkin akan mendapat efek samping lain seperti toksisitas antimikroba, infeksi nosokomial, superinfeksi jamur, serta dampak psikologi dan keuangan akibat rawat inap. ${ }^{18}$ Median suhu demam pada pasien kanker payudara stadium lanjut sedikit lebih rendah, yaitu $38,4^{\circ} \mathrm{C}$ ibanding $38,5^{\circ} \mathrm{C}$ pada pasien kanker payudara stadium awal. Suhu demam tertinggi tercatat pada kelompok pasien kanker payudara stadium lanjut dengan $39,2^{\circ} \mathrm{C}$. Median pemberian G-CSF pada pasien kanker payudara stadium awal kelompok generik B lebih banyak dibanding kelompok generik A, yaitu 4 vial dibanding 3 vial. Sedangkan pemberian G-CSF pada pasien kanker payudara stadium lanjut kelompok generik A lebih banyak dibanding kelompok generik B, yaitu 6 vial dibanding 2 vial. Hal ini akan memengaruhi besaran total biaya rawat. Perbedaan besarnya jumlah vial G-CSF yang diberikan pada pasien dipengaruhi oleh jenis kemoterapi mielospuresif dan jaminan pembiayaan pasien.

Distribusi median biaya medis langsung tiap kelompok seftazidim pada pasien kanker payudara stadium awal dan lanjut dapat dilihat pada Tabel 4 dan Tabel 5. 
Tabel 2: Lama hari rawat, suhu demam dan pemberian G-CSF pada kelompok generik A dan B pasien kanker payudara stadium awal

\begin{tabular}{lccc} 
Parameter & Total & Generik A & Generik B \\
\hline $\begin{array}{l}\text { Lama hari rawat (hari) } \\
\text { Median }\end{array}$ & 7 & 7 & 3 \\
Rentang & $3-19$ & $3-19$ & 3 \\
\hline Ratarata suhu demam ('celcius) & & & \\
Median & 38,5 & 38,7 & 38,3 \\
Rentang & $38,2-38,8$ & $38,2-38,8$ & 38,3 \\
\hline Pekerjaan (\%) & 2,5 & 3 & 4 \\
Median & $1-4$ & $1-3$ & 4 \\
Rentang & & & \\
\hline
\end{tabular}

Keterangan: G-CSF $=$ granulocyte-colony stimulating factor

Tabel 3: Lama hari rawat, suhu demam dan pemberian G-CSF pada kelompok generik A dan B pasien kanker payudara stadium lanjut

\begin{tabular}{lccc} 
Parameter & Total & Generik A & Generik B \\
\hline Lama hari rawat (hari) & & & \\
Median & 8,5 & 10 & 4 \\
Rentang & $4-16$ & $7-16$ & 4 \\
\hline Ratarata suhu demam (' ${ }^{\circ}$ celcius) & & & \\
Median & 38,4 & 38,55 & 38,4 \\
Rentang & $38,4-39,2$ & $38,4-38,7$ & 38,4 \\
\hline Pekerjaan (\%) & 4 & & \\
Median & 4 & 6 & 2 \\
Rentang & $0-10$ & $0-10$ & 2 \\
\hline
\end{tabular}

Keterangan: $\mathrm{G}-\mathrm{CSF}=$ granulocyte-colony stimulating factor

Tabel 4: Distribusi median biaya medis langsung pasien kanker payudara stadium awal berdasarkan kelompok seftazidim

\begin{tabular}{lccc} 
& \multicolumn{2}{c}{ Median biaya (rupiah) } & \\
\cline { 2 - 3 } Parameter & Generik A & Generik B & \\
\hline Biaya seftazidim & 186.642 & 331.812 & 0,655 \\
Biaya rawat inap & 2.375 .000 & 1.125 .000 & 0,346 \\
Biaya visit dokter & 1.547 .000 & 450.000 & 0,346 \\
Biaya obat lain & 4.652 .791 & 2.921 .827 & 0,180 \\
Biaya alat kesehatan & 196.816 & 85.968 & 0,655 \\
Biaya penunjang & 2.913 .000 & 1.606 .000 & 0,655 \\
Biaya administrasi & $463.992,45$ & $195.618,21$ & 0,655 \\
Total biaya medis langsung & $15.930 .407,45$ & $6.716 .225,21$ & 0,655 \\
\hline
\end{tabular}

Keterangan: $\mathrm{P}$ value $=$ nilai signifikansi; $\mathrm{P}$ value $>0,05$ berarti tidak ada perbedaan bermakna antara dua komponen biaya kelompok generik $\mathrm{A}$ dan generik $\mathrm{B}$
Tabel 5: Distribusi median biaya medis langsung pasien kanker payudara stadium lanjut berdasarkan kelompok seftazidim

\begin{tabular}{|c|c|c|c|}
\hline \multirow{2}{*}{ Parameter } & \multicolumn{2}{|c|}{ Median biaya (rupiah) } & \multirow{2}{*}{$P$ value } \\
\hline & Generik A & Generik B & \\
\hline Biaya seftazidim & 421.344 & 205.860 & 0,480 \\
\hline Biaya rawat inap & 2.667 .500 & 2.525 .000 & 1,000 \\
\hline Biaya visit dokter & 1.200 .000 & 1.150 .000 & 1,000 \\
\hline Biaya obat lain & 8.634 .522 & 1.791 .450 & 0,480 \\
\hline Biaya alat kesehatan & $713.154,5$ & 155.183 & 0,157 \\
\hline Biaya penunjang & 1.907 .750 & 1.112 .271 & 0,157 \\
\hline Biaya administrasi & $464.927,75$ & $208.192,92$ & 0,157 \\
\hline Total biaya medis langsung & $15.962 .519,25$ & $7.147 .956,92$ & 0,157 \\
\hline
\end{tabular}

Keterangan: $\mathrm{P}$ value $=$ nilai signifikansi; $\mathrm{P}$ value $>0,05$ berarti tidak ada perbedaan bermakna antara dua komponen biaya kelompok generik A dan generik B

Tabel 6: Perhitungan ACER tiap kelompok seftazidim pasien kanker payudara stadium awal

\begin{tabular}{lccc} 
Jenis seftazidim & total biaya (C) & $\begin{array}{c}\text { lama hari } \\
\text { rawat (E) }\end{array}$ & ACER (C/E) \\
\hline Generik A & Rp 15.930.407,45 & 7 hari & Rp 2.275.772,49/hari \\
Generik B & Rp 6.716.225,21 & 3 hari & Rp 2.238.741,74/hari \\
\hline
\end{tabular}

Tabel 7: Perhitungan ACER tiap kelompok seftazidim pasien kanker payudara stadium awal

\begin{tabular}{lcrc} 
Jenis seftazidim & total biaya (C) & $\begin{array}{r}\text { lama hari } \\
\text { rawat (E) }\end{array}$ & ACER (C/E) \\
\hline Generik A & Rp 15.962.519,25 & 10 hari & Rp 1.596.251,92/hari \\
Generik B & Rp 7.147.956,92 & 4 hari & Rp 1.786.989,23/hari \\
\hline
\end{tabular}

Pada analisis biaya dari Tabel 4 dan Tabel 5 diketahui bahwa biaya seftazidim pada kelompok generik A lebih rendah dibanding kelompok generik B. Hal ini disebabkan pada kelompok generik A meski inisial terapi empiris diawali dengan terapi tunggal seftazidim, terjadi penggantian dengan antibiotik lain akibat demam yang menetap atau didapatkannya hasil uji kultur mikroorganisme yang bersifat lebih rentan terhadap antibiotik lain. Perhitungan ACER tiap kelompok seftazidim pada pasien kanker payudara stadium awal dan lanjut dapat dilihat pada Tabel 6 dan Tabel 7. Di Rumah Sakit Kanker "Dharmais" terdapat fasilitas VVIP, VIP, kelas I, II, dan III. Biaya rawat inap kelompok generik A lebih tinggi dari kelompok generik B disebabkan oleh perbedaan median lama hari rawat. Dari Tabel 2 dan Tabel 3 diketahui bahwa median lama rawat generik A memang lebih panjang, yaitu 7 hari dibanding 3 hari pada pasien kanker payudara stadium awal dan 10 hari dibanding 4 hari pada pasien kanker payudara stadium lanjut. Serupa 
dengan biaya rawat inap, besaran biaya visit kelompok generik A yang lebih tinggi juga disebabkan oleh perbedaan median lama hari rawat.

Posisi penggunaan seftazidim generik A dan B pada pasien kanker payudara stadium awal dan lanjut dalam diagram efektivitas biaya dapat dilihat pada Gambar 1 dan Gambar 2. Hasil analisis sensitivitas dapat dilihat pada Tabel 8 dan Tabel 9 . Pada pasien kanker payudara stadium awal, total biaya kelompok generik $\mathrm{B}$ yang lebih rendah membuat kelompok generik B berada pada posisi dominan pada diagram efektivitas biaya dengan total biaya yang lebih rendah dan efektivitas yang lebih tinggi. Sedangkan kelompok generik A dengan total biaya yang lebih tinggi dan efektivitas lebih rendah (median lama hari rawat lebih panjang) berada dalam posisi terdominasi sehingga kelompok seftazidim generik B merupakan seftazidim yang lebih cost-effective. Rasio biaya rupiah per hari yang dilakukan dengan perhitungan ACER memberikan hasil besaran biaya yang sedikit lebih rendah pada kelompok generik B dibanding kelompok generik A, yaitu sebesar Rp 2.238.741,74/hari dibanding Rp 2.275.772,49/hari. Analisis sensitivitas memberikan hasil bahwa pemilihan generik B sensitif terhadap kenaikan biaya $25 \%$ di mana nilai ACER generik B akan lebih tinggi dibanding baseline nilai ACER generik A. Pemilihan generik B juga sensitif terhadap penurunan biaya $25 \%$ pada kelompok generik A di mana nilai ACER generik A akan lebih rendah dibanding baseline nilai ACER generik B. Nilai ACER generik $B$ yang lebih rendah dengan lama hari rawat yang lebih singkat membuat total biaya kelompok generik B jauh lebih rendah dibanding kelompok generik A. Oleh karena itu, seftazidim generik B merupakan seftazidim yang lebih cost-effective. Pada pasien kanker payudara stadium lanjut, total biaya kelompok generik B yang lebih rendah membuat kelompok generik B berada pada posisi dominan pada diagram efektivitas-biaya dengan total biaya yang lebih rendah dan efektivitas yang lebih tinggi, sedangkan kelompok generik A dengan total biaya yang lebih tinggi dan efektivitas lebih rendah (median lama hari rawat lebih panjang) berada dalam posisi terdominasi sehingga kelompok seftazidim generik B merupakan seftazidim yang lebih cost-effective. Rasio biaya rupiah per hari yang dilakukan dengan perhitungan ACER memberikan hasil besaran biaya yang lebih rendah pada kelompok generik A dibanding kelompok generik $\mathrm{B}$, yaitu sebesar $\mathrm{Rp}$ 1.596.251.92/hari dibanding Rp 1.786.989.23/hari. Analisis sensitivitas memberikan hasil generik A sensitif terhadap kenaikan biaya 25\%, di mana nilai ACER generik A akan lebih tinggi dibanding baseline nilai ACER generik B. Sedangkan generik B juga sensitif terhadap penurunan biaya 25\% di mana nilai ACER generik B akan lebih rendah dibanding baseline nilai ACER generik A. Nilai ACER atau rasio biaya per hari kelompok generik $B$ memang lebih besar dibanding kelompok generik A, namun dengan median lama hari rawat yang lebih singkat membuat total biaya kelompok generik B jauh lebih rendah dibanding kelompok generik A.

\begin{tabular}{|ccccc|}
\hline & & \multicolumn{3}{c|}{ Biaya alternatif A terhadap alternatif B } \\
\cline { 2 - 5 } & & Lebih rendah & Sama & Lebih tinggi \\
\hline Efektivitas & Lebih tinggi & $\begin{array}{c}\text { Generik B } \\
\text { (dominan) }\end{array}$ & + & $\begin{array}{c}+/- \\
\text { (tukaran) }\end{array}$ \\
\cline { 2 - 5 } $\begin{array}{c}\text { alternatif A } \\
\text { terhadap } \\
\text { alternatif B }\end{array}$ & Sama & + & Diantara & - \\
\cline { 2 - 5 } & Lebih rendah & $\begin{array}{c}+/- \\
\text { (tukaran) }\end{array}$ & - & $\begin{array}{c}\text { Generik A } \\
\text { (didominasi) }\end{array}$ \\
\hline
\end{tabular}

Gambar 1: Posisi penggunaan antibiotik seftazidim generik A dan generik B pasien kanker payudara stadium awal dalam diagram efektivitas-biaya

\begin{tabular}{|ccccc|}
\hline & & \multicolumn{3}{c|}{ Biaya alternatif A terhadap alternatif B } \\
\cline { 2 - 5 } & & Lebih rendah & Sama & Lebih tinggi \\
\hline \multirow{2}{*}{$\begin{array}{c}\text { Efektivitas } \\
\text { alternatif A } \\
\text { terhadap } \\
\text { alternatif B }\end{array}$} & Lebih tinggi & $\begin{array}{c}\text { Generik B } \\
\text { (dominan) }\end{array}$ & + & + Sama \\
\cline { 2 - 5 } & Lebih rendah & + & Diantara & (tukaran) \\
\hline
\end{tabular}

Gambar 2: Posisi penggunaan antibiotik seftazidim generik A dan generik B pada pasien kanker payudara stadium lanjut dalam diagram efektivitas-biaya

Oleh karena itu, seftazidim generik B merupakan seftazidim yang lebih cost-effective.

Tabel 8: Analisis sensitivitas tiap kelompok seftazidim pada pasien kanker payudara stadium awal

\begin{tabular}{lccc} 
Sensitivitas & Biaya (C) & $\begin{array}{c}\text { lama hari } \\
\text { rawat(E) }\end{array}$ & ACER (C/E) \\
\hline Generik A & & & \\
Penurunan 0\% & Rp 15.930.407,45 & 7 hari & Rp 2.275.772,49/hari \\
Penurunan 25\% & Rp 11.947.805,59 & 7 hari & Rp 1.706.829,37/hari \\
Penaikan 25\% & Rp 19.913.009,18 & 7 hari & Rp 2.844.715,62/hari \\
Generik B & & & \\
Penurunan 0\% & Rp 6.716.225,21 & 3 hari & Rp 2.238.741,74/hari \\
Penurunan 25\% & Rp 5.037.168,91 & 3 hari & Rp 1.679.056,30/hari \\
Kenaikan 25\% & Rp 8.395.281,51 & 3 hari & Rp 2.798.427,17/hari \\
\hline
\end{tabular}




\begin{tabular}{|c|c|c|c|}
\hline Sensitivitas & Biaya (C) & $\begin{array}{l}\text { lama hari } \\
\text { rawat (E) }\end{array}$ & ACER (C/E) \\
\hline \multicolumn{4}{|l|}{ Generik A } \\
\hline Penurunan 0\% & Rp $15.962 .519,25$ & 10 hari & Rp 1.596.251,92/hari \\
\hline Penurunan 25\% & Rp 11.971.889,44 & 10 hari & Rp 1.197.188,94/hari \\
\hline Kenaikan 25\% & Rp 19.953.149,06 & 10 hari & Rp 1.995.314,91/hari \\
\hline \multicolumn{4}{|l|}{ Generik B } \\
\hline Penurunan 0\% & Rp 7.147.956,92 & 4 hari & Rp 1.786.989,23/hari \\
\hline Penurunan 25\% & Rp 5.037.168,91 & 4 hari & Rp 1.340.241.92/hari \\
\hline Kenaikan 25\% & Rp 8.395.281,51 & 4 hari & Rp 2.233.736,54/hari \\
\hline
\end{tabular}

\section{KESIMPULAN}

Berdasarkan analisis efektivitas biaya, seftazidim generik B pada pasien kanker payudara stadium awal maupun lanjut (dengan nilai ACER berturutturut Rp 2.238.741,74/hari dan Rp 1.786.989.23/hari) lebih cost-effective dibanding generik A (dengan nilai ACER berturut-turut Rp 2.275.772,49/hari dan Rp 1.596.251.92/hari).

\section{DAFTAR PUSTAKA}

1. Hadinegoro, Sri Rezeki S. Demam pada Pasien Neutropenia. Sari Pediatri 2002;3:35-241.

2. Egerer et al. Continuous infusion of ceftazidime for patients with breast cancer and multiple myeloma receiving high-dose chemotherapy and peripheral blood stem cell transplantation. Bone MarrowTransplant 2002;30:427-431.

3. Rascati, K.I., Drummond, M.F., Annemans, I. \& Davey, P.G. Education in Pharmacoeconomics: an Internasional Multidiciplinary View (Review). Pharmaco Economics 2004;22:39-47.

4. Walley, Tom. Pharmacoeconomics and Economic Evaluation of Drug Therapies (pp. 68-73). UK: Liverpool, 2004

5. Honneycutt, A.A, et al. Guide to Analyzing the Cost-Effectiveness of Community Public Health Prevention Approaches (pp. 56-57). USA: Research Triangle Park, 2006.

6. David, E., et al. Decision Analysis of Antibiotic and Diagnostic Strategies in Ventilator-associated Pneumonia. American Journal of Respiratory and Critical Care Medicine 2003;168(9): 1060-1067.
7. Polednak, A.P. Surveillance for hospitalizations with infectionrelated diagnoses after chemotherapy among breast cancer patients diagnosed before age 65. Chemotherapy 2004;50(4): 157-161.

8. Adams, J.R., Angelotta, C., $\&$ Bennet, C. When the Risk of Febrile Neutropenia Is 20\%, Prophylactic Colony-Stimulating Factor Use Is Clinically Effective, but Is It Cost-Effective. JCO 2006;24(19):2975-2977.

9. Nani, Desiyani. Hubungan Umur Awal Menopause dan Status Penggunaan Kontrasepsi Hormonal dengan Kejadian Kanker Payudara. Jurnal Keperawatan Soedirman The Soedirman Journal of Nursing 2009;4(3):102-106.

10. Pasko, M.T., Beam, T.R., Sponer, J.A. \& Camara, D.S. Safety and pharmacokinetics of ceftazidime in patients with chronic hepatic dysfunction. J Antimicrob Chemother 1985;15(3):365374.

11. Ballot, J., McDonnel, D., \& Crown, J. Successful Treat ment of Thrombocytopenia Due to Marrow Metastases of Breast Cancer with Weekly Docetaxel. J Natl Cancer Inst 2003;95(11):831832.

12. Oliver, T.B., Bhat,R., Kellet, C.F. \& Adamson, D.J. Diagnosis and management of bone metastases. JR CollPhysicians 2011;41:330-338

13. Aapro, et al. 2010 update of EORTC guidelines for the use of granulocytecolony stimulating factor to reduce the incidence of chemotherapy-induced febrile neutropenia in adult patients with lymphoproliferative disorders and solid tumours. European Journal of Cancer 2010; 47: 8-32.

14. National Comprehensive Cancer Network. (2013). NCCN Clinical Practice Guideline Oncology: Myeloid Growth Factors. Februari 8, 2013.

15. http://www.nccn.orgGunawan, S.G., (Ed.). Farmakologi danTerapi edisi 5 (pp. 593, 678-686). Jakarta: Fakultas Kedokteran Universitas Indonesia, 2007

16. Skeel, R.T. (Ed.). Handbook of Cancer Chemotherapy (pp. 634-665). USA: Lippincott Williams \& Wilkins; 2008.

17. Chisholm-Burns et al (Eds.). Pharmacotherapy: Principles and Practice (pp. 1297, 1303-1321). New York : McGraw-Hill, 2008.

18. Hai Pun, E., et al. Cancer Patients with Fever and Neutropenia: A Prospective Evaluation of Risk Assessment Tools and Infectious Etiology in Hong Kong (pp. 5). Hongkong : Health and Health Services Research Fund, 2009. 